\title{
ІНСТИТУЦОНАЛЬНІ ОСНОВИ ЕКОЛОГО- ЕКОНОМІЧНОЇ ЕФЕКТИВНОСТІ СІЛЬСЬКОГОСПОДАРСЬКОГО ЗЕМЛЕКОРИСТУВАННЯ
}

Комарова Н. В., РhD з економіки, Білочерківський наиіональний аграрний університет, Украӥна Прядка Т. М., к.е.н., доцент, Білочерківський національний аграрний університет, Украйна Комаров Д. Ю., асистент, Білоиерківський національний аграрний університет, Украӥна Камінецька О. В., к.е.н., Білочерківський начіональний аграрний університет, Україна Кочеригін Л. Ю., к.п.н., Білочерківський начіональний аграрний університет, Україна

\section{DOI: https://doi.org/10.31435/rsglobal_conf/25022021/7415}

Abstract. It is proved that increasing the level of anthropogenic loading on agroecosystem leads to negative destructive changes in the state of agricultural land, which poses a potential threat to the level of agroecological and food safety. Under of the existing organizational and economic conditions of commodity production in the crop production sector, there are no trends towards positive changes in the expansion of the complex of implementation of land conservation measures and the prudent attitude towards the use of agricultural land. Instead, the increase in profits and yields, the expansion of arable land in the narrowing of the agricultural land provoke a decrease in the level of agroecological safety, the spread of erosion and degradation processes, the decrease of humus stocks and the level of fertility However, despite the increase in the economic efficiency of the crop sub-sector of agriculture, the scope and organization of the implementation of measures to restore and preserve agroresource potential require radical changes on scientifically grounded positions.

Keywords: agro-resource potential, level of agroecological safety, commodity plant growing production, state of the environment, level of anthropogenic loading, balanced land use, agricultural land, soils, economic responsibility for soil condition.

Вступ. Рівень агроекологічної безпеки визначається мірою антропогенного навантаження на довкілля та обсягами зусиль, спрямованих на відновлення і збереження прийнятного стану навколишнього природного середовища і агроресурсного потенціалу зокрема, які можна оцінити за допомогою низки статистичних показників. Баланс вказаних зусиль забезпечує оптимізацію співвідношення між обсягами товарного виробництва сільськогосподарської продукції та станом довкілля, тобто між економічними інтересами агровиробників та екологічними запитами суспільства. Втім, упродовж останніх десятиліть агровиробничі процеси, i насамперед у рослинництві, засновано на організаційно-економічних підходах, що здебільшого фокусуються на нарощуванні потужності виробничо-сировинної ланки. Це забезпечило можливість нарощування обсягів експорту сільськогосподарської продукції (переважно у вигляді сировини), збільшення прибутків агровиробництва завдяки розширенню площ під найбільш рентабельні культури та росту показників їх урожайності. Але нехтування агровиробниками вимог забезпечення ощадливого землекористування та збереження родючості земель сільськогосподарського призначення має високий рівень потенційної загрози продовольчій безпеці, що напряму залежить від якісного стану грунтового покриву та призводить до економічних збитків суспільства. Виправлення існуючої ситуації потребує організаційно-економічних змін, спрямованих на коригування диспропорцій у системі еколого-економічної ефективності сільськогосподарського землекористування через впровадження комплексу науково обгрунтованих заходів. Це потребує посилення інституціональної основи іiі забезпечення для формування економічної відповідальності землекористувачів за якісний стан грунтового покриву агроугідь, які задіяні у процесі товарного виробництва рослинництва, а саме - нормативно-законодавчих вимог забезпечення моніторингової, сертифікаційної компоненти запровадження дозвільної системи з регулювання процесів використання земель сільськогосподарського призначення.

Мета роботи полягає в систематизації чинників агроекологічної безпеки, що на основі детального підтвердження статистичною звітністю обгрунтовує комплекс заходів не лише землеохоронного спрямування, а орієнтованих на забезпечення прийнятного рівня агроекологічної 
безпеки. Предметом дослідження $є$ сукупність теоретичних аспектів удосконалення організаційноекономічних умов землекористування щодо запровадження економічної відповідальності агровиробників товарної продукції рослинництва за якісний стан грунтів.

Результати досліджень. Оновлення організаційно-економічних умов товарного виробництва рослинництва 3 метою запровадження економічної відповідальності агровиробників за якісний стан грунтового покриву земель сільськогосподарського призначення після їх використання грунтується на удосконаленні нормативно-законодавчої основи, розвитку інституційної складової та інформаційно-реєстраційної інфраструктури. Зазначене потребує удосконалення теоретичного підгрунтя 3 ключовим компонентом систематизації факторів та показників, з яких походить комплекс землеохоронних заходів.

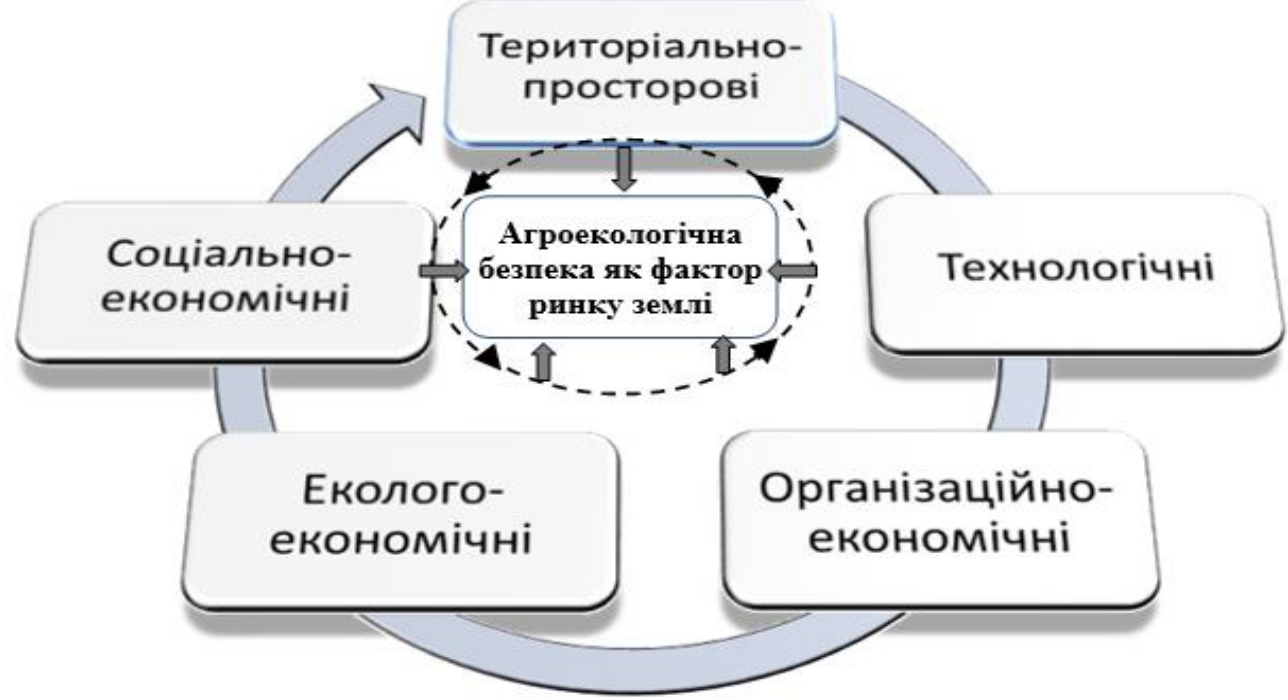

Рис.1. Система факторів агроекологічної безпеки у контексті вільного економічного обігу земельних ділянок сільськогосподарського призначення

На схемі позначено зв'язки: $\Rightarrow$ - основні (прямі); $\rightarrow-$ зворотні (допоміжні).

Їх поділ та систематизація є дещо умовним, але вплив відбувається комплексно, створюючи сублімований ефект. Запропонований перелік не є ранжированим, адже ієрархія характеристик доволі різниться для кожного конкретного випадку, і міра впливу кожної $з$ груп чинників визначається організаційно-економічними, еколого-економічними, соціальноекономічними умовами господарювання, тобто формується структура чинників впливу на рівень агроекологічної безпеки. Сублімований ефект впливу системи чинників має як прямий, так і зворотний ефект, що відображено на рис. 1.

Наприклад, розташування типів грунтів визначає вибір технологій їх обробітку, від чого залежить необхідність застосування певних видів обладнання, структура добривних матеріалів, що у сумі визначає обсяги матеріально-фінансових витрат та прибутковість діяльності. В умовах технічного прогресу розвиток техніки і технологій надає змогу отримувати високі показники врожаїв завдяки агроресурсному потенціалу, але нехтування вимогам щодо ощадливого використання земель сільськогосподарського призначення врешті-решт призводить до його виснаження. У підсумку збільшуються темпи і обсяги деградації земель, активізуються процеси ерозії, з'являється необхідність використання додаткових площ під посіви, а недостатній рівень вжиття землеохоронних заходів знижує значення коефіцієнтів екологічної стабільності.

3 огляду на викладене, можемо стверджувати, що інтегральною характеристикою рівня агроекологічної безпеки і еколого-економічної ефективності сільськогосподарської діяльності можна вважати динаміку запасів гумусу у грунтовому покриві агроугідь, які використовують під обробіток з метою виробництва товарної продукції. У процесі виконання дослідження нами здійснено спробу проведення оцінки економічної ефективності господарювання під час виробництва товарної продукції рослинництва у Київській обл. і її порівняння з національним рівнем, а також отриманих результатів 3 показниками екологічної ефективності господарювання (табл. 1). 
Таблиця 1. Показники ефективності землекористування у товарному виробництві рослинництва в Україні і Київській області

\begin{tabular}{|c|c|c|c|c|c|c|c|c|c|}
\hline \multirow[t]{2}{*}{ Показник } & \multicolumn{9}{|c|}{ Рік } \\
\hline & 2010 & 2011 & 2012 & 2013 & 2014 & 2015 & 2016 & 2017 & $\begin{array}{c}2017 / \\
2010, \%\end{array}$ \\
\hline \multicolumn{10}{|c|}{$\begin{array}{c}\text { Продуктивність праці у сільськогосподарських підприсмствах (на } 1 \text { зайнятого в } \\
\text { сільськогосподарському виробництві у постійних цінах } 2010 \text { року), тис. грн }\end{array}$} \\
\hline Україна & 132,7 & 165,2 & 159,7 & 201,2 & 227,7 & 223,3 & 275,3 & 271,5 & 204,6 \\
\hline Київська обл. & 143,3 & 180,3 & 193,2 & 204,5 & 236,0 & 226,9 & 250,2 & 251,0 & 175,1 \\
\hline \multicolumn{10}{|c|}{ Індекси валової продукції сільського господарства, \% до попереднього року } \\
\hline Україна & 98,5 & 119,9 & 95,5 & 113,3 & 102,2 & 95,2 & 106,3 & 97,8 & \\
\hline Київська обл. & 99,4 & 118,6 & 108,5 & 101,3 & 105,9 & 89,2 & 109,8 & 95,7 & \\
\hline \multicolumn{10}{|c|}{$\begin{array}{c}\text { Продукція рослинництва у господарствах усіх категорій з розрахунку на } 100 \text { га } \\
\text { сільськогосподарських угідь, тис. грн }\end{array}$} \\
\hline Україна & 334,7 & 437,5 & 402,1 & 483,6 & 500,6 & 474,2 & 520,1 & $\mathrm{H} /$ д & 155,4 \\
\hline Київська обл. & 433,2 & 549 & 595,6 & 601,6 & 658,8 & 562,3 & 667,7 & $\mathrm{H} /$ Д & 154,1 \\
\hline \multicolumn{10}{|c|}{$\begin{array}{c}\text { Виробництво валової продукції сільського господарства на одну особу у постійних цінах } \\
2010 \text { року, грн }\end{array}$} \\
\hline Україна & 4249 & 5113 & 4897 & 5559 & 5847 & 5589 & 5967 & 5865 & 138,0 \\
\hline Київська обл. & 2547 & 3011 & 3251 & 3272 & 3447 & 3058 & 3343 & 3184 & 125,0 \\
\hline \multicolumn{10}{|c|}{ Площа сільськогосподарських угідь, тис. га } \\
\hline Україна & 41576,0 & 41557,6 & 41536,3 & 41525,8 & 41511,7 & 41507,9 & 41504,9 & 41489,3 & 99,8 \\
\hline Київська обл. & 1664,9 & 1664,2 & 1664,2 & 1664,2 & 1664,2 & 1664,2 & 1658,8 & 1651,5 & 99,2 \\
\hline \multicolumn{10}{|c|}{ - 3 них рілля } \\
\hline Україна & 32476,5 & 32498,5 & 32518,4 & 32525,5 & 32531,1 & 32541,3 & 32543,4 & 32544,3 & 100,2 \\
\hline Київська обл. & 1356,2 & 1355,5 & 1355,5 & 1355,5 & 1355,5 & 1355,5 & 1353,7 & 1351,5 & 99,7 \\
\hline \multicolumn{10}{|c|}{ Посівні площі сільськогосподарських культур, тис. га } \\
\hline Україна & 26952,0 & 27670,0 & 27801,0 & 28329,0 & 27239,0 & 26901,8 & 27026,0 & 27585,0 & 102,3 \\
\hline Київська обл. & 1111,2 & 1134,6 & 1153,5 & 1160,0 & 1155,4 & 1153,0 & 1164,0 & 1184,0 & 106,6 \\
\hline \multicolumn{10}{|c|}{$\begin{array}{c}\text { Внесення добрив під сільськогосподарські культури на } 1 \text { га посівної площі } \\
\bullet \quad \text { мінеральні, кг поживної речовини } \\
\end{array}$} \\
\hline Україна & 58 & 68 & 72 & 80 & 82 & 79 & 96 & 110 & 189,7 \\
\hline Київська обл. & 71 & 78 & 81 & 93 & 95 & 87 & 108 & 128 & 180,3 \\
\hline \multicolumn{10}{|c|}{ - органічні, т } \\
\hline Україна & 0,5 & 0,5 & 0,5 & 0,5 & 0,5 & 0,5 & 0,5 & 0,5 & 100,0 \\
\hline Київська обл. & 1,2 & 1,5 & 1,4 & 1,3 & 1,7 & 1,4 & 1,2 & 1,3 & 108,3 \\
\hline \multicolumn{10}{|c|}{ Наявність тракторів у сільськогосподарських підприємствах на кінець року, тис. шт. } \\
\hline Україна & 151,3 & 147,1 & 150,7 & 146,0 & 130,8 & 127,9 & 132,7 & 129,3 & 85,5 \\
\hline Київська обл. & 8,6 & 8,0 & 8,3 & 8,4 & 7,9 & 8,0 & 8,3 & 8,0 & 93,0 \\
\hline \multicolumn{10}{|c|}{$\begin{array}{l}\text { Забезпеченість енергетичними потужностями сільськогосподарських підприсмств, кВт на } \\
100 \text { га посівної площі }\end{array}$} \\
\hline Україна & 193 & 187 & 213 & 218 & 208 & 166 & 175 & 165 & 85,5 \\
\hline Київська обл. & 273 & 268 & 255 & 261 & 231 & 246 & 260 & 236 & 86,4 \\
\hline
\end{tabular}

Джерело: дані [1-6]

3 огляду на наведену статистичну інформацію, прослідковується чітка тенденція до підвищення економічних показників земле користування під час товарного виробництва рослинницької продукції. Так, загальна кількість агропідприємств, які отримали чистий прибуток, неухильно зростає — від 69,6\% у 2010 р. до 86,7\% у 2017 р.

Збільшились показники виробництва валової продукції у ціновому вимірі 2010 р. в усіх категоріях господарств у розрахунку на 100 га сільськогосподарських угідь, зокрема у рослинництві України - на $55,4 \%$ і на $54,1 \%$ у Київській обл. одночасно 3 обсягами виробництва на одну особу на $38 \%$ і на $25 \%$, відповідно. Закономірним є збільшення частки сільськогосподарського виробництва у динаміці показника валової доданої вартості від 8,4\% у 2010 р. до 12,1\% у 2017 р. Найбільший вплив на досягнення таких результатів забезпечено збільшенням обсягів внесення мінеральних добрив у вимірі поживних речовин у 2017 р. у 1,7 рази на національному рівні і більш, ніж у 1,5 рази у Київській обл. 
Також спостерігається збільшення площ, які були оброблені засобами захисту рослин, у т. ч. і пестицидами. Так, у 2010 р. заходи з хімізації в Україні були проведені на площі понад 12,2 млн га (у т. ч. пестицидами - 10,8 млн га), а у 2016 р. ці показники становили 14,3 млн га (у т. ч. пестицидами - 13,8 млн га, що становить майже $22 \%$ ). У Київській обл. збільшення площі застосування пестицидів відбувається дещо повільніше - на 17\% у 2016 р. (530,4 тис. га) порівняно 3 440,3 тис. га у 2010 p. Водночас обсяги внесення органічних добрив в Україні залишаються на мінімальному рівні - 0,5 т внесення під сільськогосподарські культури у розрахунку на 1 га, хоча у Київській обл. зафіксовано деяку позитивну динаміку цього показника за останні сім років - на 1 ц/га від 1,2 т у 2010 р. до 1,3 т на 1 га посівної площі у 2017 р. Проте мусимо констатувати про негативні тенденції у динаміці площ угідь сільськогосподарського призначення попри, деяке скорочення в України за період оцінювання на рівні $0,2 \%$, що становить майже 87 тис. га; у Київській обл. це скорочення становить $0,8 \%$, або 13,4 тис. га. На цьому тлі площі орних земель в Україні зросли на 67,8 тис. га, а у Київській обл. ці показники хоча і скоротились, проте у менших обсягах попри скорочення агроугідь - лише на $0,3 \%$, що становить 4,7 тис. га.

Про зростання антропогенного навантаження свідчить динаміка посівних площ у межах орних земель, яка демонструє значно вищі темпи розширення: для України цей показник збільшився на 2,3\% (633 тис. га) упродовж 2010-2017 р., а у Київській обл. - майже на 7\% (72,8 тис. га). Ресурсною базою вказаних тенденцій $є$ скорочення площ перелогів, багаторічних насаджень, тобто тих категорій земель, які створюють знижені рівні антропогенного навантаження на агроекосистему, що негативно впливає на стан агроекологічної безпеки. Важливою характеристикою землекористування у рослинництві є структура посівних площ, яка свідчить про переважання економічних інтересів над екологічними. Зокрема, площа посівів пшениці зросла від 5,3 млн га у 2000 р. до 6,1 млн га у 2010 p., а у 2017 р. цей показник становив 6,2 млн га. Площі посівів соняшнику розширились більш ніж удвічі і становили у 2017 р. понад 6 млн га; у 2010 р. - 4,6 млн га (для порівняння - площа екостабілізуючих угідь у сільському господарстві станом на 01.01.2016 р. становила 8,8 млн га [3]).

Значно більші темпи приросту демонструють площі посівів ріпаку та кукурудзи на зерно, які збільшились у понад 3 рази з 2000 до 2017 року: від 0,2 млн га до майже 0,8 млн га та від 1,4 млн га до 4,5 млн га відповідно. Натомість площа посівів кормових культур зазнала за період 2000-2017 рр. значних скорочень: під посівами кукурудзи кормової скоротились у понад 6 разів, трав'яних культур - утричі. Також слід враховувати зростання рівня антропогенного навантаження у агроекосистемах, що зумовлено збільшенням показників урожайності майже всіх сільськогосподарських культур, зокрема, врожайність пшениці зросла від 26,8 ц з га у 2010 р. до 41,1 ц $з$ га у 2017 р. в Україні і від 25,1 ц/га у 2010 р. до 35,3 ц/га у 2017 р. у Київській обл.; кукурудзи на зерно - 345,1 до 55,1 і з 54,1 до 60,2 ц/га; соняшнику і ріпаку - від 15 та 17 ц/га до 20,2 та 27,9 ц/га у 2017 р. в Україні і від 18,4 та 13,5 ц/га у 2010 р. до 24,1 та 26,5 ц/га у 2017 р. у Київській обл. відповідно.

Крім того, спостерігається зниження рівня матеріально-ресурсного забезпечення сільськогосподарських підприємств, зокрема наявність енергетичних потужностей наприкінці року у перерахунку на 100 га посівної площі скоротилась у 2017 р. порівняно з 2010 р. на 14,5\% в Україні і на 13,6\% у Київській обл. Також спостерігається скорочення загальної кількості наявних тракторів за вказаний період - на 14,5 та 7\% в Україні і у Київській обл. відповідно, що свідчить про скорочення витрат на оновлення парку сільськогосподарської техніки.

Висновки. Доведено виснажливий вплив чинної організації землекористування з метою товарного виробництва рослинницької продукції. Проаналізовано чинники агроекологічної безпеки, запропоновано систематизацію та продемонстровано їх зв'язок з комплексом заходів відтворення і збереження агроресурсного потенціалу. На основі аналізу статистичних даних 3 урахуванням динаміки показників якісного стану грунтового покриву на землях сільськогосподарського призначення висвітлено необхідність запровадження організаційноекономічних змін у агровиробництві. Цільовим призначенням цих змін має бути посилення відповідальності землекористувачів за якісний стан грунтів агроугідь, що є ресурсною основою товарного виробництва та збільшення економічних прибутків, і у такий спосіб забезпечення прийнятного рівня агроекологічної безпеки. 3 іншого боку, існує необхідність забезпечення фінансово-економічної підтримки агровиробників через можливість отримання кредитів, позик, пільг під час оподаткування чи стягнення виплат. 


\section{REFERENCES}

1. Trofimtseva O. (2018), The official site of The Ukrainian Stockbreeders Association «Ukrainian agroexport amounted to $\$ 8.6$ billion over 6 months of $2018 »$, available at: https://usba.com.ua/en/ukrainianagroexportamounted-86-billion-over-6-months-2018 (Accessed 4 January 2018).

2. Korenyuk, P. \& Chmulenko, N. (2012). Metodyka otsinky efektyvnosti vykorystannya ta vidtvorennya produktyvnykh uhid' sil's'kohospodars'kykh pidpryyemstv [Methodology for evaluating the efficiency of use and reproduction of productive lands of agricultural enterprises]. Ekonomist [Economist], 1, 47-50. (In Ukr.)

3. State Statistics Service of Ukraine (2018), «Roslynnytstvo Ukrayiny 2017. Statystychnyj zbirnyk» [Plant Growing of Ukraine 2017. Statistical yearbook], Derzhkomstat, Kyiv, Ukraine.

4. State Statistics Service of Ukraine (2018), «Sil's'ke hospodarstvo Ukrayiny 2017. Statystychnyj zbirnyk» [Agriculture of Ukraine 2017. Statistical yearbook], Derzhkomstat, Kyiv, Ukraine.

5. State Statistics Service of Ukraine (2018), «Statystychnyy shchorichnyk Ukrayiny za 2017 rik. Statystychnyj zbirnyk» [Statistical Yearbook of Ukraine for 2017. Statistical yearbook], Derzhkomstat, Kyiv, Ukraine.

6. The Main Department of Statistics in the Kyiv region (2019), «Sotsial'no-ekonomichne stanovyshche Kyyivs'koyi oblasti za 2018 rik. Statystychnyy byuleten'» [Socio-economic situation of the Kiev region in 2018. Statistical bulletin, Kyiv, Ukraine 